\title{
MUTU ORGANOLEPTIK CIDER JAMBU BIJI (Psidium guajava) PADA VARIETAS YANG BERBEDA
}

\author{
Ida Nurhayati \\ Jurusan Gizi Poltekkes Kemenkes Medan
}

\begin{abstract}
Abstrak
Indonesia termasuk negara penghasil buah-buahan. Dengan berlimpahnya buah-buahan maka dilakukan pengawetan. Cider (Anggur buah) merupakan salah satu cara pengawetan untuk menambah nilai ekonomis buah, selain itu cider merupakan salah satu minuman beralkhohol yang rasanya manis, mempunyai aroma harum dan khas dibuat melalui fermentasi khamir jenis Sacharomyces cerevisiae. Buah jambu biji mempunyai kadar vitamin C tinggi yaitu 87\% dan vitamin A 25\% serta kandungan karbohidrat 12,2\%, selain itu juga mengandung zat mineral, besi, fosfat dan kapur.(Rismunandar,1997).Cider telah lama dikenal sejak berabad-abad yang lalu sebagai minuman tradisional Negara Timur Tengah dan Eropa. Adanya kemajuan teknologi kini minuman anggur tidak hanya dibuat dari beras atau buah anggur namun buah buahan yang rasanya manis juga dapat dibuat cider. Penelitian ini bertujuan untuk mengetahui mutu organoleptik cider jambu biji dengan varietas yang berbeda (yaitu cider dari jambu biji biasa dibandingkan dengan cider dari jambu biji bangkok). Penilaian mutu organoleptik dilakukan dengan cara menilai warna, rasa, aroma dan konsistensi cider jambu biji. Selanjutnya dilakukan penghitungan kadar alkohol yang dihasilkan oleh cider tersebut. Penelitian ini bersifat eksperimen yang dilakukan pada tanggal 10-17 Maret 2003 di laboratorium Teknologi Pangan Jurusan Gizi Poltekkes Medan. Pembuatan cider jambu biji biasa dan jambu biji bangkok masing-masing dilakukan dengan ulangan sebanyak dua kali. Penelitian ini menggunakan 2 (dua) perlakuan dan 2 (dua) ulangan sehingga terdapat 4 (empat) unit percobaan. Terdapat perbedaan nyata rasa (F hitung 8,82 > F tabel 3,34) dan aroma (F hitung 10,44 $>\mathrm{F}$ tabel 3,34) antara cider jambu biji biasa dengan jambu biji bangkok. Namun warna ( $F$ hitung 2,24 $>\mathrm{F}$ tabel 4,20) dan kekentalan (F hitung 2,64 < F tabel 3,34) tidak menunjukkkan perbedaan nyata. Mutu organoleptik yang meliputi warna, rasa, aroma dan kekentalan cider jambu biji biasa lebih disukai dari pada jambu biji bangkok. Mutu organoleptik yang meliputi warna, rasa, aroma dan kekentalan cider jambu biji biasa lebih disukai dari pada jambu biji bangkok. Kandungan alkohol cider jambu biji biasa setelah fermentasi 7 hari adalah 13\% sedangkan kandungan alkohol cider jambu biji bangkok 13,6\%.
\end{abstract}

Kata kunci: Mutu organoleptik, cider jambu biji

\section{PENDAHULUAN}

Pengawetan buah-buahan dapat dilakukan dengan bermacam-macam cara antara lain dengan fermentasi. Cider (Anggur buah) merupakan salah satu minuman beralkhohol yang rasanya manis. Mempunyai aroma yang harum dan khas dibuat melalui fermentasi khamir jenis Sacharomyces cerevisiae.

Buah jambu biji mempunyai kadar vitamin $\mathrm{C}$ tinggi yaitu $87 \%$ dan vitamin A $25 \%$ serta kandungan karbohidrat $12,2 \%$, selain itu juga mengandung zat mineral, besi, fosfat dan kapur. Rismunandar (1997) mengatakan buah jambu biji umumnya digunakan oleh masyarakat untuk mencegah penyakit sariawan dan untuk meningkatkan daya tahan terhadap infeksi.

Cider telah lama dikenal sejak berabad-abad yang lalu sebagai minuman tradisional Negara Timur Tengah dan Eropa. Adanya kemajuan teknologi kini minuman anggur tidak hanya dibuat dari beras atau buah anggur namun buah -buahan yang rasanya manis juga dapat dibuat cider.

Jambu biji banyak dijumpai di pasaran. Menurut data Badan Pusat Statistik (BPS) Sumatera Utara tahun 2000 bahwa rata -rata produksi tanaman jambu biji adalah 16,43 ton meningkat dari tahun sebelumnya. Dengan demikian salah satu upaya untuk meningkatkan nilai ekonomis jambu biji adalah dengan pembuatan cider atau anggur buah. Dari hal tersebut penulis mencoba meneliti pembuatan cider dari jambu biji dengan varietas yang berbeda, yaitu dengan menggunakan jambu biji biasa dibandingkan dengan jambu biji bangkok yang selanjutnya akan dinilai mutu organoleptiknya.

\section{TUJUAN}

Penelitian ini bertujuan untuk mengetahui mutu organoleptik cider jambu biji dengan varietas yang berbeda (yaitu cider dari jambu biji biasa 
dibandingkan dengan cider dari jambu biji bangkok). Penilaian mutu organoleptik dilakukan dengan cara menilai warna, rasa, aroma dan konsistensi cider jambu biji. Selanjutnya dilakukan penghitungan kadar alkohol yang dihasilkan oleh cider tersebut.

\section{METODE}

Penelitian ini bersifat eksperimen yang dilakukan pada tanggal 10-17 Maret 2003 di laboratorium Teknologi Pangan Jurusan Gizi Poltekkes Medan. Pembuatan cider jambu biji biasa dan jambu biji bangkok masing-masing dilakukan dengan ulangan sebanyak dua kali. Penelitian ini menggunakan 2 (dua) perlakuan dan 2 (dua) ulangan sehingga terdapat 4 (empat) unit percobaan.

Bahan : Jambu biji bangkok dan biasa masing-masing 2 $\mathrm{kg}$, gula pasir 1200 gr, ragi Sacharomyces cereviciae sebanyak 60 gr dan Aquadesh 2 ltr.

Alat : Pisau, wakskom, timbangan duduk, blender, kain saring, gelas ukur, Erlenmeyer, inkubator, beaker glass, thermometer, autoclave, hot plate, spatula, selang fermentasi.

Prosedur :

Pembuatan starter dan sari buah

1) Jambu biji dikupas, dicuci dan dihancurkan dengan blender hingga menjadi bubur jambu biji. 2) Ditambahkan aquadesh 1:1 dari volume bubur jambu biji. 3) Disaring untuk diambil sarinya dan diukur volumenya. 4) Ditambahkan gula pasir 20\% dari volume sari buah. 5) Diambil $100 \mathrm{ml}$ sari buah kemudian ditambahkan ragi Sacharomyces cereviciae 1\%. 6) Diaduk hingga rata dan dimasukkan kedalam inkubator selama 24 jam dengan suhu $30^{\circ} \mathrm{C}$ hingga timbul gas. 7) Sari buah selebihnya setelah diambil untuk pembuatan starter dipanteurisasi selama 1 jam dalam autoclave.

Peragian/Fermentasi

1) Larutan starter yang sudah jadi dimasukkan ke dalam sari buah yang sudah dipasteurisasi dalam erlemmeyer. 2) Erlenmeyer ditutup menggunakan gabus yang tengahnya sudah diberi selang, kemudian ujung selang yang lain dicelupkan ke dalam beaker glass yang berisi air. 3) Diinkubasikan dalaminkubator selama 7 hari dengan suhu $30^{\circ} \mathrm{C}$.

Pemeraman1) Setelah fermentasi 7 hari, dilakukan pasteurisasi selama 1 jam dengan suhu $70^{\circ} \mathrm{C}$. 2) Cider dipindahkan ke dalam botol yang sudah disterilkan. 3) Disimpan lagi ke dalam inkubator pada suhu $30^{\circ} \mathrm{C}$ selama 7 hari.

Perhitungan kadar alkohol (UI, 1997)

$\mathrm{t}_{\mathrm{a}}=\mathrm{t}_{\text {cider sebelum fermentasi }}-\mathrm{t}_{\text {aquadesh sebelum fermentasi }}$

$\mathrm{t}_{\mathrm{b}}=\mathrm{t}_{\text {cider sesudah fermentasi }}-\mathrm{t}_{\text {aquadesh sesudah fermentasi }}$

$\Delta_{\mathrm{t}}=\mathrm{t}_{\mathrm{b}}-\mathrm{t}_{\mathrm{a}} \longrightarrow$ Dikonversikan dalam tabel Steinkrous

$\mathrm{t}=$ titik didih

Tingkat kesukaan konsumen yang meliputi warna, rasa, aroma dan kekentalan diujikan ke 30 orang panelis terlatih. Adapun skala pengukuran yang digunakan skala sebagai berikut : 1 = Tidak suka, $2=$ Agak suka, $3=$ Suka, $4=$ Amat suka,

5 = Amat sangat suka.

\section{HASIL DAN PEMBAHASAN}

Warna merupakan daya tarik suatu produk makanan. Konsumen dalam memilih makanan pertama kali sangat dipengaruhi oleh warna. Warna cider jambu biji secara umum adalah hijau muda sampai dengan hijau tua.

\section{TINGKAT KESUKAAN KONSUMEN}

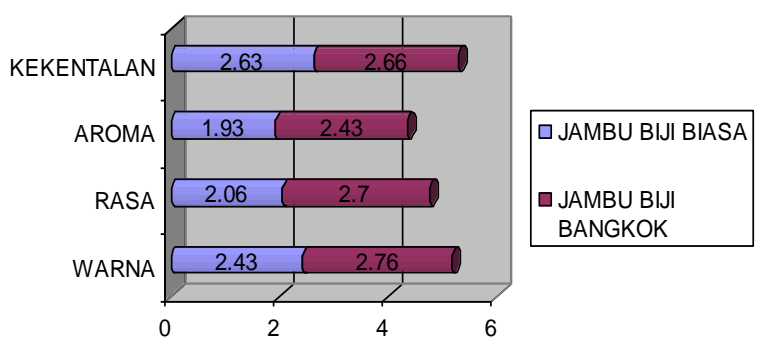

Hasil penelitian menunjukkan tidak ada perbedaan nyata antara warna cider jambu biji biasa dan warna cider jambu biji bangkok (F hitung 2,24 < F tabel 4,20).

Rasa cider jambu biji dalam penelitian ini terdapat perbedaan nyata antara rasa cider jambu biji biasa dan jambu biji bangkok ( $F$ hitung 8,82 > F tabel $3,34)$. Rasa cider adalah manis disertai asam dan adanya rasa segar pada waktu diminum, hal ini disebabkan adanya proses fermentasi dalam pembuatan cider jambu biji. Bahan dasar cider ini adalah karbohidrat sehingga setelah difermentasikan dapat menghasilkan alkohol dan $\mathrm{CO}_{2}$ yang menyebabkan rasa segar dalam cider.

Aroma merupakan bagian penting dan sangat menentukan kualitas minuman cider. Dalam penelitian ini terdapat perbedaan nyata antara aroma jambu biji biasa dengan jambu biji bangkok ( $\mathrm{F}$ hitung 10,44 > F tabel 3,34) Aroma cider dalam penelitian ini adalah spesifik aroma jambu biji.

Kekentalan cider jambu biji biasa dan jambu biji bangkok tidak menunjukkan perbedaan nyata ( $\mathrm{F}$ hitung 2,64 $<\mathrm{F}$ tabel 3,34). Kekentalan cider dipengaruhi oleh bahan-bahan untuk pembuatan cider Yaitu jambu biji, ragi dan gula.

\section{SIMPULAN}

1. Warna cider jambu biji biasa tidak menunjukkan perbedaan nyata dibandingkan dengan cider dari jamu biji bangkok dalam taraf agak suka dan suka.

2. Rasa cider jambu biji biasa menunjukkan perbedaan nyata dibandingkan dengan rasa cider dari jamu biji bangkok dalam taraf suka dan agak suka.

3. Aroma cider jambu biji biasa menunjukkan perbedaan nyata dibandingkan dengan cider dari jamu biji bangkok yaitu pada taraf agak suka.

4. Kekentalan cider jambu biji biasa tidak menunjukkan perbedaan nyata dibanding dengan 
cider dari jamu biji bangkok yaitu pada taraf suka.

5. Mutu organoleptik yang meliputi warna, rasa, aroma dan kekentalan cider jambu biji biasa lebih disukai dari pada jambu biji bangkok.

6. Kandungan alkohol cider jambu biji biasa setelah fermentasi 7 hari adalah $13 \%$ sedangkan kandungan alkohol cider jambu biji bangkok $13,6 \%$.

\section{RUJUKAN}

Ansori Rahman, 1999, Pengantar Teknologi Fermentasi, Depdikbud Dirjen Dikti PAU Pangan dan Gizi, IPB Bogor.

Astawan, Made Wahyuni, Mia, 1991, Teknologi Tepat Guna. Akademika Presindo. Jakarta.

Biro Pusat Statistik , 2000, Kabupaten Deli Serdang, Propinsi Sumatera Utara.

Bukle, K.A, 1978. Technology in Preservation, In a Course Manual in Food Science, Australian Vice Chancellors Committe.
Daulay, Rahman Djunjun Ansori, 1992. Teknologi Fermentasi Sayur dan buah-buahan. Dep. P dan K, PAU Pangan dan Gizi, IPB, Bogor.

Desrosier, Norman.W, 1988. Teknologi Pengawetan Pangan, UI, Jakarta.

Fardiaz, Srikandi, 1992. Mikrobiologi Pengolahan Pangan Lanjutan. Gramedia Pustaka Utama. Jakarta.

Kapti Rahayu dan Slamet Sudarmadji, 1988. Prosesproses Mikrobiologi Pangan, PAU Pangan dan Gizi UGM Yogyakarta.

Rismunandar, 1997, Tanaman Jambu Biji, Sinar Baru Bandung.

Santoso, Hieronymus Budi, 1996. Teknologi Tepat Guna Anggur Pisang, Kanisius, Yogyakarta.

Winarno, F.G, 1995, Kimia Pangan dan Gizi, Gramedia, Jakarta

Winarno, F.G, 1999, Sterilisasi Komersial Produk Pangan, Gramedia, Jakarta

Winarno, F.G, 2000. Kerusakan bahan Pangan dan Cara Pencegahannya, Ghalia Indonesia Jakarta 